TRADITIONAL ENGLISH GRAMMAR AND BEYOND 
Related Macmillan titles:

SHAKESPEARE'S LANGUAGE: AN INTRODUCTION N. F. Blake

A GUIDE TO CHAUCER'S LANGUAGE

David Burnley

SEMIOTICS AND THE PHILOSOPHY OF LANGUAGE Umberto Eco

VARIETIES OF ENGLISH

Dennis Freeborn

A GOURSE BOOK IN ENGLISH GRAMMAR

Dennis Freeborn

LITERARY LANGUAGE FROM GHAUGER TO JOHNSON

A. J. Gilbert

THE DICTIONARY OF EVEN MORE DISEASED

ENGLISH

Kenneth Hudson

THE LANGUAGE OF THE TEENAGE REVOLUTION Kenneth Hudson

ENGLISH GRAMMAR FOR TODAY

A New Introduction

Geoffrey Leech, Margaret Deuchar and Robert Hoogenraad

A DIGTIONARY OF GOOD ENGLISH

A Guide to Current Usage

S. G. McKaskill 


\section{TRADITIONAL ENGLISH GRAMMAR AND BEYOND}

N. F. BLAKE

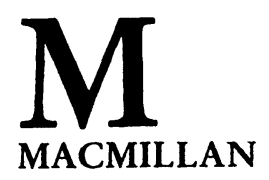


(c) N. F. Blake 1988

Softcover reprint of the hardcover 1st edition 1988 978-0-333-39920-0

All rights reserved. No reproduction, copy or transmission of this publication may be made without written permission.

No paragraph of this publication may be reproduced, copied or transmitted save with written permission or in accordance with the provisions of the Copyright, Designs and Patents Act 1988, or under the terms of any licence permitting limited copying issued by the Copyright Licensing Agency, 90 Tottenham Court Road, London W1P 9HE.

Any person who does any unauthorised act in relation to this publication may be liable to criminal prosecution and civil claims for damages.

First published 1988 by THE MACMILLAN PRESS LTD

Houndmills, Basingstoke, Hampshire RG21 2XS and London

Companies and representatives

throughout the world

ISBN 978-0-333-39921-7 ISBN 978-1-349-19006-5 (eBook) DOI 10.1007/978-1-349-19006-5

A catalogue record for this book is available from the British Library.

Reprinted 1992 


\section{Contents}

Preface vii

Introduction 1

1 Review of Word Classes 14

2 Nouns and Associated Word Classes 29

3 The Verb and its Constituents 48

4 The Other Classes $\quad 66$

5 Recapitulation and Development 82

6 The Make-up of Clauses $\quad 98$

7 Glause Elements and Sentence Types 114

8 Clause Types 127

9 Conclusion 143

$\begin{array}{lr}\text { Suggested Further Reading } & 150\end{array}$

$\begin{array}{ll}\text { Index } & 152\end{array}$ 
For Dorinda Jane 


\section{Preface}

There are many reasons why you should want to pick up a book which has Grammar in its title, and those reasons are so diverse that it is not possible for a single book to satisfy them all. So I need to offer a brief explanation as to why I have written this particular grammar. The study of English grammar has proceeded in the following two ways recently. Modern linguists have been obsessed with the theoretical problems of language and so have proposed new theoretical methodologies for analysing language. These have sometimes spawned grammars, which are difficult for those with no linguistic background to follow since such readers do not understand some of the preconceptions which lie behind them. On the other hand, full descriptions of English have been written such as the one by Professor Quirk and his colleagues. These often have a somewhat eclectic methodology, for they use not only traditional terminology but also some more modern terms. Those who come new to the study of the English language find both approaches rather daunting, because they have been taught neither. It is clear that there is room for an introduction to the study of English grammar which starts with traditional approaches and then incorporates some of the newer terms from modern linguistics. The new A level English Language papers established by the Joint Matriculation Board (Manchester) and the University of London Examinations Board provide a good example of this need. This book has been written with this kind of need in mind. Readers who find it helpful, but who feel modification might make the book even more useful, are invited to write to me with their suggestions.

I am indebted to my colleagues and to my students in the 
viii TRADITIONAL ENGLISH GRAMMAR AND BEYOND

Department of English Language at Sheffield University for their ideas and support with this volume. I am also grateful to many of the participants at conferences we have organised on the JMB A level English Language course for their comments, which have often helped me in deciding what to include and how to put it. I am particularly grateful to Sandra Burton, who has once again produced such excellent copy for the publishers.

NFB 